\title{
sciendo
}

\section{Endoscopic ultrasound-guided drainage of a fungal liver abscess using a lumen-apposing metal stent: case report and literature review}

\author{
FELICE MOLINARIO ${ }^{1}$, MIHAI RIMBAȘ ${ }^{2-4}$, GIUSEPPE ALESSANDRO PIROZZI ${ }^{1}$, \\ GIANENRICO RIZZATTI ${ }^{2,6}$ GIANLUCA SPERA $^{1}$, GUIDO COSTAMAGNA ${ }^{5,6}$, \\ ALBERTO LARGHI ${ }^{2,6}$ \\ ${ }^{1}$ Digestive Endoscopy Unit, Gemelli Molise Hospital, Campobasso, Italy \\ ${ }^{2}$ Digestive Endoscopy Unit, Fondazione Policlinico Universitario A. Gemelli IRCCS, Rome, Italy \\ ${ }^{3}$ Gastroenterology Department, Colentina Clinical Hospital, Bucharest, Romania \\ ${ }^{4}$ Department of Internal Medicine, Carol Davila University of Medicine, Bucharest, Romania \\ ${ }^{5}$ Digestive Endoscopy Unit, Fondazione Policlinico Universitario A. Gemelli IRCCS, Catholic University, Rome, Italy \\ ${ }^{6}$ CERTT, Center for Endoscopic Research Therapeutics and Training, Catholic University, Rome, Italy
}

\begin{abstract}
Liver abscesses are rare entities for which percutaneous drainage is traditionally employed. The technique is simple, but associated with a significant rate of side effects and patient discomfort. We herein report a case of fungal left liver lobe abscess that was successfully treated by using EUS-guided drainage, with insertion of a large caliber lumen-apposing metal stent. The literature review we performed on the topic seems to favor, at least for abscess in the left and/or caudate liver lobes, EUS as compared to percutaneous drainage.
\end{abstract}

Key words: endoscopic ultrasound; liver abscess; drainage; lumen apposing metal stents; humans.

\section{INTRODUCTION}

Liver abscesses are rare entities usually diagnosed by transabdominal ultrasound or computer tomography. Except for small abscesses, their treatment usually implies drainage achieved in most cases transcutaneously under imaging guidance. This route, however, is associated with significant rates of adverse events (AEs) and external drainage-related patient discomfort [1]. Internal drainage under endoscopic ultrasound (EUS) guidance appears an attractive minimally invasive alternative to the percutaneous one. In addition, recent development of dedicated lumen apposing metal stents (LAMS) mounted on an electrocautery enhanced delivery system, makes possible a one-step procedure with formation of a stable communication between the gastrointestinal (GI) lumen and the abscess cavity, favoring its rapid resolution.

We, herein, describe a case of EUS-guided drainage of a hepatic abscess with fungal etiology and perform a thorough literature review on this topic.

\section{CASE REPORT}

An 82 y.o. female with a 2-month history of intermittent fever of unknown etiology was referred to us to perform alcohol ablation of a $14 \times 12 \mathrm{~cm}$ cystic lesion in the left hepatic lobe, causing compression on the gastric antrum (Figure 1). At EUS, the lesion presented thickened walls, and appeared with corpusculated material inside. Aspiration of the cyst content with a 19-gauge FNA needle revealed presence of purulent material, which was sent for microbiological evaluation and culture.

After discussion with the patient of EUS findings and different therapeutic options, a decision to perform EUS-guided drainage was made. The procedure was done under deep sedation using a 10mm-long, $20 \mathrm{~mm}$-large LAMS (AXIOS ${ }^{\mathrm{TM}}$ stent) mounted on an electrocautery enhanced delivery system (Boston Scientific Corp., Marlborough, MA, US), which was placed under complete EUS control (Figures 2 and 3). Dilation of the inner part of the stent up to $20 \mathrm{~mm}$ using a dilation balloon (CRE, Boston Scientific) was performed to allow better drainage of the purulent material. The cavity was subsequently rinsed with sterile water until it was completely cleansed. An 8.5-Fr, $3 \mathrm{~cm}$-long double pig-tail plastic stent was finally placed through the Axios $^{\mathrm{TM}}$ stent and the patient discharged home the day after. Culture of the aspirated material grew Candida albicans. One month later, the cavity appeared completely resolved (Figure 4) and both stents were removed, without any abscess recurrence after two months of follow-up. 


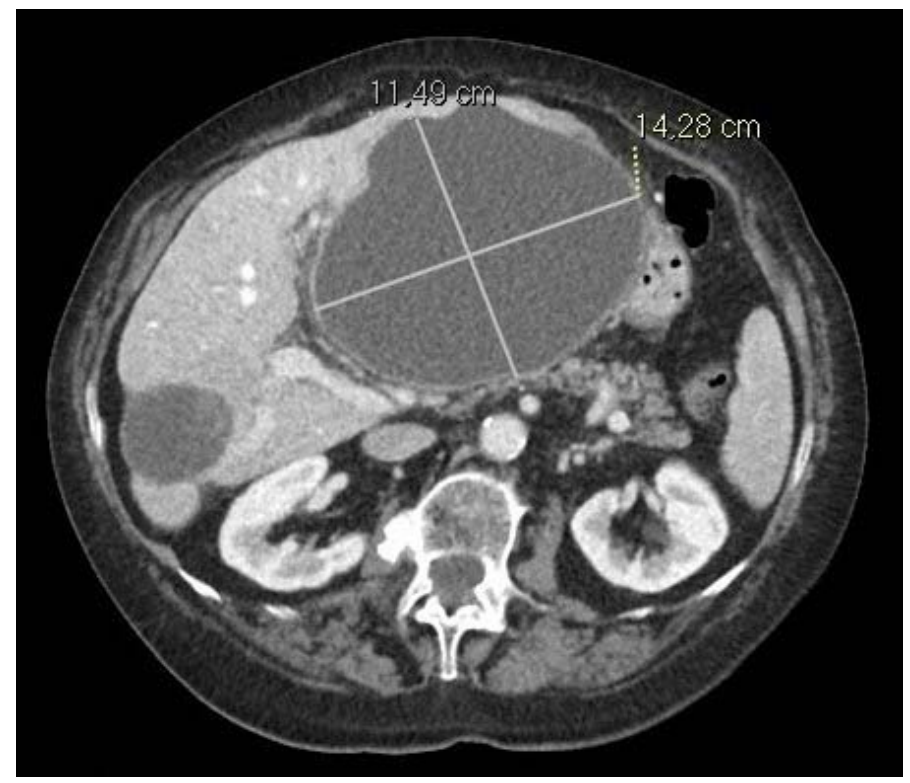

Figure 1. Abdominal CT scan image showing the large collection in the left liver lobe.

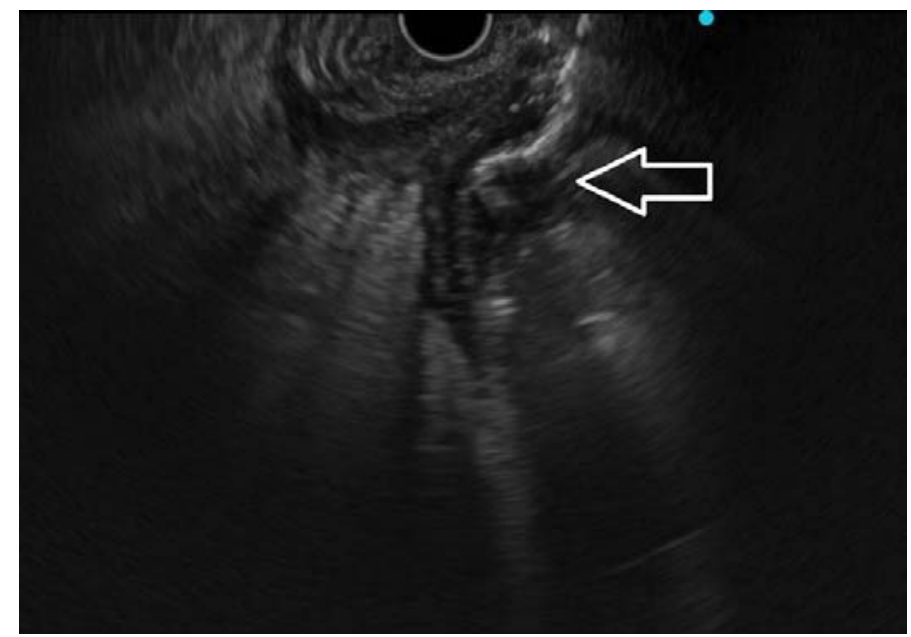

Figure 2. EUS image showing the distal flange of the AXIOS ${ }^{\mathrm{TM}}$ stent inside the collection (arrow).

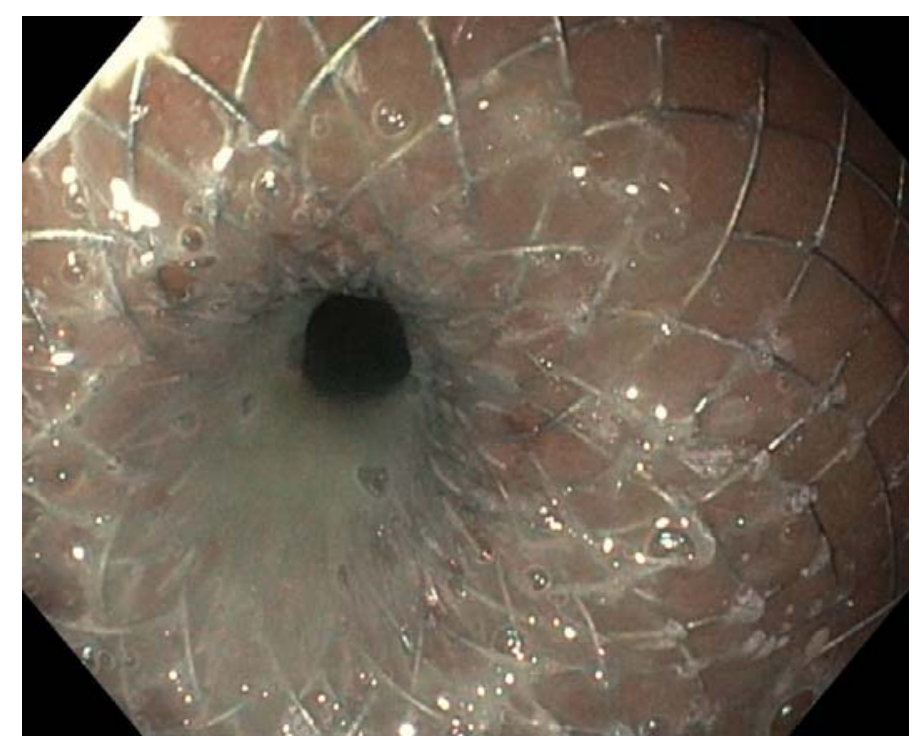

Figure 3. Endoscopic image after stent deployment showing drainage of pus through the stent into the gastric lumen. 


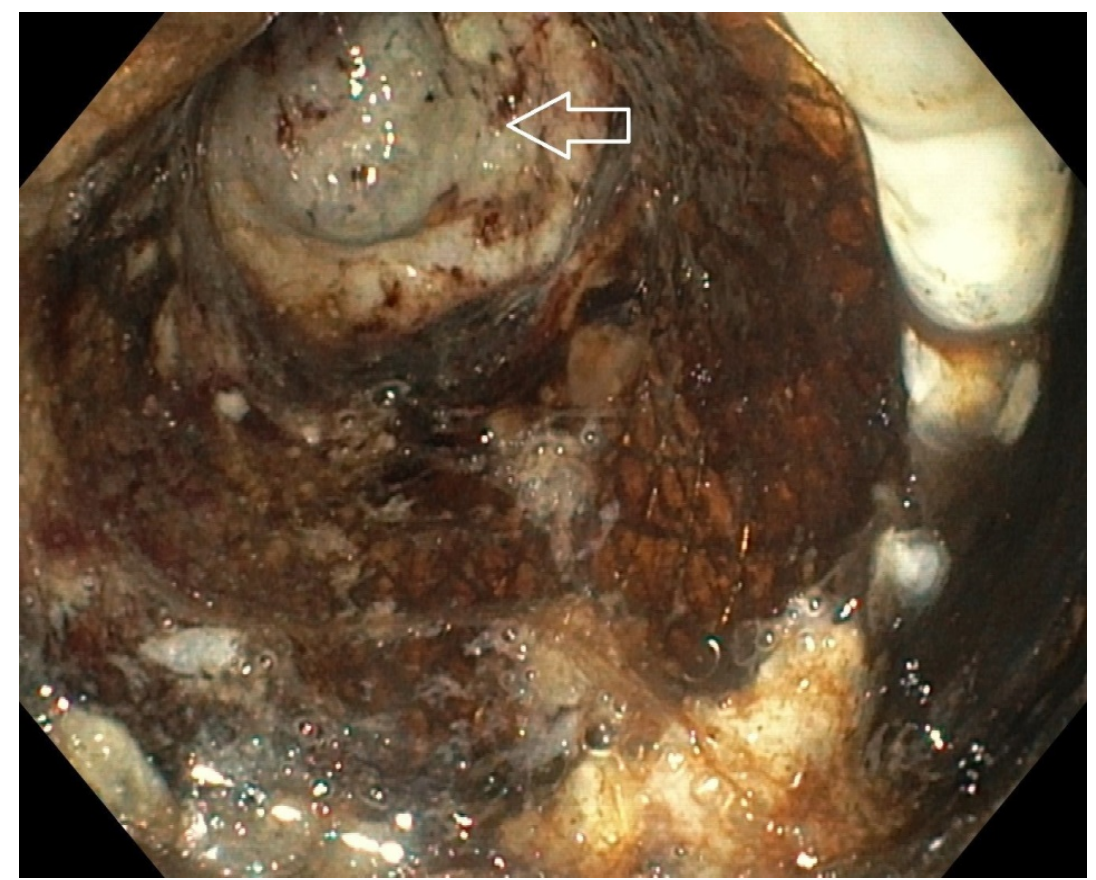

Figure 4. Endoscopic image at 1 month of follow-up showing contralateral wall of the collection in close proximity to the distal flange of the AXIOS ${ }^{\mathrm{TM}}$ stent indicative of resolution of the abscess.

\section{DISCUSSION}

Liver abscesses, usually encountered in elderly, are generally caused by biliary obstruction or instrumentation, abdominal trauma, bloodstream microorganisms' dissemination, or prior abdominal surgery [2]. Surgical drainage as a primary treatment has been abandoned due to high mortality rates (17-32\%) [3] and substituted by percutaneous drainage, which at present represents the first-line approach [4]. The technique is simple, does not require general anesthesia, but despite reported success rates of $80-100 \%$ [5], it is associated with a significant rate of serious AEs and patient discomfort [1].

EUS is rapidly evolving from a diagnostic imaging tool to a more interventional procedure able to offer a therapeutic modality for any collection adjacent to the GI tract, such as pancreatic and peri-pancreatic fluid collections [6], and abscesses located in the upper abdomen, subphrenic space, and pelvis [7-8]. The close proximity of the liver, in particular the left hepatic lobe, to the EUS transducer in the gastric cavity stimulated endosonographers to utilize EUS for hepatic abscesses drainage. Table 1 summarizes all cases reported so far, which were all retrospectively described [9-24]. Different techniques, such as EUS-guided insertion of nasoabscess drains, plastic stents, fully or partially covered self-expandable metal stents (SEMS), or LAMS have been utilized. Overall, 40 patients have been treated, mostly with abscesses in the left/caudate liver lobes $(31 / 40,77.5 \%)$, with both a technical and clinical success rate of $95 \%$. Adverse events were reported in two patients, with one case of fully covered SEMS dislodgment during lavage [23] and another one of intra-abscess SEMS migration, which was discovered few days after placement that was re-cannulated with a guidewire followed by successfully double pig-tail plastic stent insertion with clinical resolution [15].

In two studies a comparison between EUS and percutaneous liver abscess drainage was made $[19,23]$. In the first one, eight patients who underwent EUS-guided drainage using tubular SEMS due to contraindication of the percutaneous route, were compared with 19 patients treated with percutaneous drainage [19]. No significant differences in technical and clinical success rates were observed between the two groups, however AEs occurred only in the percutaneous arm (one self-removal and two migrations of the drainage tube), which had also a median hospital stay significantly longer than the EUS group (41 vs. 21 days, $p=0.03$ ) [19].

In the second study, nine patients with liver abscesses (five in the right lobe) drained under EUS guidance were compared with 27 patients who underwent percutaneous treatment. Both showed clinical resolution rate of $78.2 \%$. Unfortunately, no additional data could be obtained from the paper because liver abscesses were mixed with other upper abdominal collections [23]. 
Table 1

Summary of cases of EUS-guided liver abscess drainages reported so far

\begin{tabular}{|c|c|c|c|c|c|c|c|c|c|c|}
\hline $\begin{array}{c}\text { Author, } \\
\text { year }\end{array}$ & $\begin{array}{l}\text { No. of } \\
\text { cases }\end{array}$ & $\begin{array}{c}\text { Abscess } \\
\text { size }(\mathrm{cm})\end{array}$ & $\begin{array}{l}\text { Abscess } \\
\text { location }\end{array}$ & $\begin{array}{l}\text { Abscess } \\
\text { etiology }\end{array}$ & $\begin{array}{l}\text { Type of } \\
\text { stent } \\
\text { (internal } \\
\text { diameter) }\end{array}$ & $\begin{array}{c}\text { Coaxial } \\
\text { plastic } \\
\text { stent }\end{array}$ & $\begin{array}{c}\text { Technical/ } \\
\text { clinical } \\
\text { success (\%) }\end{array}$ & $\begin{array}{l}\text { Adverse } \\
\text { events }\end{array}$ & $\begin{array}{c}\text { Stent } \\
\text { removal }\end{array}$ & $\begin{array}{l}\text { Recurrence } \\
\text { (follow up) }\end{array}$ \\
\hline $\begin{array}{c}\text { Seewald, } \\
2005\end{array}$ & 1 & $7 \times 11$ & LL & $\begin{array}{c}\text { Escherichia } \\
\text { coli }\end{array}$ & NAC only & N/a & $\begin{array}{l}100 \% / \\
100 \%\end{array}$ & None & 7 days & \begin{tabular}{|c|} 
No \\
$(6$ months $)$ \\
\end{tabular} \\
\hline $\begin{array}{l}\text { Ang, } \\
2009\end{array}$ & 1 & $10.7 \times 5.7$ & LL & NR & DPPS & $\mathrm{N} / \mathrm{a}$ & $\begin{array}{l}100 \% / \\
100 \%\end{array}$ & None & 11 days & NR \\
\hline $\begin{array}{l}\text { Noh, } \\
2010\end{array}$ & 3 & $\begin{array}{l}5.1 \times 4 \\
4.5 \times 6 \\
5.5 \times 4\end{array}$ & $\begin{array}{c}\text { CL (2), LL } \\
\text { (1) }\end{array}$ & \begin{tabular}{|c|} 
Streptococcus \\
intermedius, \\
milleri; \\
Streptococcus \\
viridans; and \\
Streptococcus \\
constellatus, \\
milleri \\
\end{tabular} & DPPS & $\mathrm{N} / \mathrm{a}$ & $\begin{array}{l}100 \% / \\
100 \%\end{array}$ & None & $\begin{array}{c}6 \text { weeks } \\
\text { (mean) }\end{array}$ & $\begin{array}{c}\text { No } \\
\text { (mean of } \\
7.6 \text { months) }\end{array}$ \\
\hline $\begin{array}{l}\text { Itoi, } \\
2011\end{array}$ & 1 & 7.8 & $\mathrm{CL}$ and $\mathrm{LL}$ & $\begin{array}{c}\text { Mycobacterium } \\
\text { tuberculosis }\end{array}$ & $\begin{array}{c}\text { Straight PS, } \\
\text { and PDDS }\end{array}$ & N/a & & None & NR & \begin{tabular}{|c|} 
No \\
$(6$ months $)$
\end{tabular} \\
\hline \begin{tabular}{|c} 
Keohane, \\
2011
\end{tabular} & 2 & $\begin{array}{c}2.5 \times 2.5 \\
4.5 \times 2.1 \\
\end{array}$ & $\mathrm{CL}$ & $\mathrm{NR}$ & DPPS & $\mathrm{N} / \mathrm{a}$ & $\begin{array}{l}100 \% / \\
100 \%\end{array}$ & None & \begin{tabular}{|l} 
Mean of \\
53 days
\end{tabular} & NR \\
\hline \begin{tabular}{|l} 
Alcaide, \\
2013 \\
\end{tabular} & $1^{*}$ & 10 & LL & $\begin{array}{c}\text { Staphylococcus } \\
\text { aureus }\end{array}$ & $\begin{array}{l}\text { LAMS } \\
(10 \mathrm{~mm})\end{array}$ & Yes & $\begin{array}{l}100 \% / \\
100 \%\end{array}$ & None & 3 months & $\begin{array}{c}\text { No } \\
\text { (6 months) }\end{array}$ \\
\hline $\begin{array}{c}\text { Medrado, } \\
2013\end{array}$ & 1 & NR (giant) & LL & NR & $\begin{array}{l}\text { SEMS } \\
(10 \mathrm{~mm})\end{array}$ & $\begin{array}{c}\text { Initially } \\
\text { no }\end{array}$ & $\begin{array}{l}100 \% / \\
100 \%\end{array}$ & \begin{tabular}{|c|} 
Intraabscess \\
stent \\
migration
\end{tabular} & NR & $\begin{array}{c}\text { No } \\
\text { (8 weeks) }\end{array}$ \\
\hline \begin{tabular}{|c|} 
Kawakami, \\
2014
\end{tabular} & 1 & $10.3 \times 6.1$ & LL & NR & $\begin{array}{c}\text { BF-SEMS } \\
(16 \mathrm{~mm})\end{array}$ & No & $\begin{array}{l}100 \% / \\
100 \%\end{array}$ & None & NR & NR \\
\hline $\begin{array}{c}\text { Kodama, } \\
2015\end{array}$ & 1 & 11 & LL & \begin{tabular}{|} 
Streptococcus \\
agalactiae and \\
S. intermedius
\end{tabular} & $\begin{array}{l}\text { DPPS, } \\
\text { replaced } \\
\text { with a } \\
\text { SEMS } \\
(10 \mathrm{~mm})\end{array}$ & No & $\begin{array}{l}100 \% / \\
100 \%\end{array}$ & None & No & $\begin{array}{c}\text { No } \\
\text { (5 months) }\end{array}$ \\
\hline \begin{tabular}{|c} 
Koizumi, \\
2015
\end{tabular} & 1 & NR & LL & $\begin{array}{l}\text { Entamoeba } \\
\text { histolytica }\end{array}$ & NAC only & N/a & $\begin{array}{l}100 \% / \\
100 \%\end{array}$ & None & 2 weeks & $\begin{array}{c}\text { No } \\
(6 \text { months })\end{array}$ \\
\hline $\begin{array}{l}\text { Ogura, } \\
2015\end{array}$ & 8 & \begin{tabular}{|c|}
7.5 \\
(median)
\end{tabular} & $\begin{array}{c}6 \mathrm{LL}, 2 \\
\mathrm{RL}\end{array}$ & NR & $\begin{array}{l}\text { SEMS } \\
(10 \mathrm{~mm})\end{array}$ & Yes & $\begin{array}{l}100 \% / \\
100 \%\end{array}$ & None & No & $\begin{array}{c}\text { No } \\
\text { (218 days) }\end{array}$ \\
\hline $\begin{array}{c}\text { Tonozuka, } \\
2015\end{array}$ & 7 & $\begin{array}{c}7 \\
\text { (median) }\end{array}$ & $\begin{array}{c}6 \mathrm{LL}, 1 \\
\mathrm{RL}\end{array}$ & NR & $\begin{array}{l}\text { SEMS and } \\
\text { BF-SEMS } \\
(8-16 \mathrm{~mm})\end{array}$ & No & $\begin{array}{l}100 \% / \\
100 \%\end{array}$ & None & $\begin{array}{c}26 \text { days } \\
\text { (in } 29 \% \text { ) }\end{array}$ & $\begin{array}{c}\text { No } \\
\text { (80 days) }\end{array}$ \\
\hline $\begin{array}{c}\text { Kumta, } \\
2016\end{array}$ & 1 & NR & LL & NR & $\begin{array}{l}\text { LAMS } \\
(15 \mathrm{~mm})\end{array}$ & Yes & $\begin{array}{l}100 \% / \\
100 \%\end{array}$ & None & 2 weeks & $\begin{array}{c}\text { No } \\
\text { (1 month) }\end{array}$ \\
\hline \begin{tabular}{|c|} 
Yamamoto, \\
2017
\end{tabular} & 1 & NR & RL & NR & NAC only & $\mathrm{N} / \mathrm{a}$ & $\begin{array}{l}100 \% / \\
100 \%\end{array}$ & None & No & $\begin{array}{c}\text { No } \\
\text { (3 weeks) }\end{array}$ \\
\hline $\begin{array}{c}\text { Carbajo, } \\
2019\end{array}$ & 9 & $\begin{array}{c}6.5 \\
\text { (median) }\end{array}$ & $\begin{array}{c}4 \mathrm{LL}, 5 \\
\mathrm{RL}\end{array}$ & $\begin{array}{c}\text { Cultures in } 15 \\
\text { resulted sterile } \\
\text { (in four), } \\
\text { monomicrobial } \\
\text { (in seven) and } \\
\text { polymicrobial } \\
\text { (in four) }\end{array}$ & NR & NR & \begin{tabular}{|c|}
$77.8 \% /$ \\
$77.8 \%$ \\
(inaccesible \\
collection, \\
and stent \\
dislogment \\
in one case \\
each) \\
\end{tabular} & $\begin{array}{c}\text { FCSEMS \& } \\
\text { dislogment } \\
\text { during } \\
\text { lavage }\end{array}$ & $\begin{array}{c}\text { In } 50 \% \text { of } \\
\text { cases after } \\
\text { a mean of } \\
92 \text { days }\end{array}$ & $\begin{array}{c}\text { No } \\
\text { (19.5 months) }\end{array}$ \\
\hline $\begin{array}{c}\text { Venkatesh, } \\
2020\end{array}$ & 1 & \begin{tabular}{|c|}
$2.4 \times 3.2 \times 2$ \\
.2
\end{tabular} & LL & $\begin{array}{c}\text { Entamoeba } \\
\text { histolytica }\end{array}$ & DPPS & $\mathrm{N} / \mathrm{a}$ & $\begin{array}{l}100 \% / \\
100 \%\end{array}$ & None & 8 weeks & \begin{tabular}{|c} 
No \\
(20 weeks)
\end{tabular} \\
\hline $\begin{array}{c}\text { Present } \\
\text { case }\end{array}$ & 1 & 10 & LL & $\begin{array}{l}\text { Candida } \\
\text { albicans }\end{array}$ & LAMS (20) & Yes & $\begin{array}{l}100 \% / \\
100 \%\end{array}$ & None & 1 month & $\begin{array}{c}\text { No } \\
\text { (2 months) }\end{array}$ \\
\hline
\end{tabular}

NAC, naso-abscess catheter; NR, not reported; N/a, not applicable; DPPS, double pigtail plastic stents; PS, plastic stent; SEMS, tubular self-expandable metal stent; BF-SEMS, bi-flanged self-expandable metal stent; FC, fully covered; GI, gastrointestinal; LL, left liver lobe; CL, caudate liver lobe; RL, right liver lobe

* This case is also included in the cohort of 18 patients from Carbajo et al.

${ }^{\&}$ Adverse events were not reported separately for the liver abscesses, but for the whole cohort of upper abdominal abscesses 
In the case herein described, the first to report EUS-guided drainage of a liver abscess of fungal etiology, we placed the largest available AXIOS ${ }^{\mathrm{TM}}$ stent (diameter $20 \mathrm{~mm}$ ) followed by immediate stent dilation to allow drainage of all purulent material from the abscess cavity into the stomach. In addition, we performed lavage to facilitate resolution of the infection. All these maneuvers are now possible due to the development of secure anastomotic stent technology through LAMS specifically designed for EUS-guided drainage (AXIOS-EC ${ }^{\text {TM }}$, Boston Scientific Corp., and SPAXUSTM and HOT SPAXUSTM, TaeWoong Medical Co., Ltd., Gimpo-si, Geyonggi-do, South Korea). Once placed, the stent makes a tight apposition between the fluid cavity and Gl lumen, minimizing the risk of leakage of purulent material into the abdominal cavity. They are fully covered, easy to remove, and the cystotome on their tip allows a one-step deployment procedure avoiding accessories exchange. Their design provides patency rates superior to those of traditional double-pigtail plastic stents, and similarly to the other SEMS they may exert hemostasis of bleeding vessels within the anastomosis tract through their radial expansion force [20]. Their large internal diameter and anchoring flanges also allow safe direct endoscopic inspection and debridement of the abscess cavity by passage of a standard gastroscope through their lumen [7].

Despite only non-prospective comparative studies are available due to the rarity of liver abscesses, EUS-guided drainage especially when performed with LAMS seems to have several advantages over the percutaneous route. It can be used when the latter is contraindicated (presence of ascites or inaccessible abscess location) [11,22], avoids the infection risks associated with the presence of an external fistula, and spares the patients from the uncomfortable feeling of an external drain attached to their abdomen. EUS-guided liver abscess drainage for multiple concomitant abscesses or for abscesses in the right liver lobe seems more difficult, even though some successful cases have been described [25].

In conclusion, we report a successful EUSguided drainage of a fungal hepatic abscess in the left lobe using a large LAMS and review the literature, which seems to favor EUS as compared to percutaneous drainage at least for abscess in the left or caudate liver lobes. Although at present the technique is mostly used in tertiary referral centers, prospective randomized studies are needed before EUS can become standard of care over percutaneous drainage for routine hepatic abscess drainage.

Abcesele hepatice sunt entități rare pentru care drenajul percutanat este utilizat in mod tradițional. Tehnica este simplă, dar asociată cu o rată semnificativă de efecte secundare și disconfort al pacientului. In lucrarea de față raportăm un caz de abces fungic al lobului stâng hepatic, care a fost tratat cu succes prin utilizarea drenajului ecoendoghidat, cu inserarea unui stent metalic de tip ,"lumen-apposing” de calibru mare. Revizuirea literaturii de specialitate efectuată pe această temă pare să favorizeze, cel puțin pentru abcesele în lobul hepatic stâng sau/și caudat, drenajul ecoendoscopic în comparație cu drenajul percutanat.

Correspondence to: Alberto Larghi MD, PhD, Digestive Endoscopy Unit, Fondazione Policlinico Universitario A. Gemelli IRCCS Università Cattolica del Sacro Cuore, Largo A. Gemelli 8, 00168, Rome, Italy

Tel. $+39 / 0630156580$

Fax $+39 / 0630156581$

E-mail: alberto.larghi@yahoo.it

Conflict of interest disclosure: The authors have no conflict of interest.

\section{REFERENCES}

1. KAWAGUCHI H. Analysis of percutaneous hepatic abscess drainage with an emphasis on factors influencing clinical outcome. Nippon Igaku Hoshasen Gassai Zasshi. 1995; 55: 34-43.

2. ALVAREZ PÉREZ JA., GONZÁLEZ JJ., BALDONEDO RF., SANZ L., CARREÑO G., JUNCO A., et al. Clinical course, treatment, and multivariate analysis of risk factors for pyogenic liver abscess. Am J Surg. 2001; 181: 177-86.

3. VOGL TJ., ESTIFAN F. Pyogenic liver abscess: Interventional versus surgical therapy: Technique, results and indications. Rofo. 2001; 173: 663-7.

4. SOLOMKIN JS., MAZUSKI JE., BRADLEY JS., RODVOLD KA., GOLDSTEIN EJ., BARON EJ., et al. Diagnosis and management of complicated intra-abdominal infection in adults and children: guidelines by the Surgical Infection Society and the Infectious Diseases Society of America. Clin Infect Dis. 2010; 50: 133-64. 
5. RAJAK CL., GUPTA S., JAIN S., CHAWLA Y., GULATI M., SURI S. Percutaneous treatment of liver abscesses: needle aspiration versus catheter drainage. AJR Am J Roentgenol. 1998; 170: 1035-9.

6. ARVANITAKIS M., DUMONCEAU JM., ALBERT J., BADAOUI A., BALI MA., BARTHET M., et al. Endoscopic management of acute necrotizing pancreatitis: European Society of Gastrointestinal Endoscopy (ESGE) evidence-based multidisciplinary guidelines. Endoscopy. 2018; 50: 524-46.

7. MUDIREDDY PR., SETHI A., SIDDIQUI AA., ADLER DG., NIETO J., KHARA H., et al. EUS-guided drainage of postsurgical fluid collections using lumen-apposing metal stents: a multicenter study. Gastrointest Endosc. 2018; 87: $1256-62$.

8. FERNANDEZ-URIEN I., VILA JJ., JIMENEZ FJ. Endoscopic ultrasound-guided drainage of pelvic collections and abscesses. World J Gastrointest Endosc. 2010; 2: 223-7.

9. SEEWALD S., IMAZU H., OMAR S., GROTH S., SEITZ U., BRAND B., et al. EUS-guided drainage of hepatic abscess. Gastrointest Endosc. 2005; 61: 495-8.

10. ANG TL., SEEWALD S., TEO EK., FOCK KM., SOEHENDRA N. EUS-guided drainage of ruptured liver abscess. Endoscopy. 2009; 41 Suppl 2: E21-2.

11. NOH SH., PARK DH., KIM YR., CHUN Y., LEE HC., LEE SO., et al. EUS-guided drainage of hepatic abscesses not accessible to percutaneous drainage (with videos). Gastrointest Endosc. 2010; 71: 1314-9.

12. ITOI T., ANG TL., SEEWALD S., TSUJI S., KURIHARA T., TANAKA R., et al. Endoscopic ultrasonography-guided drainage for tuberculous liver abscess drainage. Dig Endosc. 2011; 23 Suppl 1: 158-61.

13. KEOHANE J., DIMAIO CJ., SCHATTNER MA., GERDES H. EUS-guided transgastric drainage of caudate lobe liver abscesses. J Interv Gastroenterol. 2011; 1: 139-41.

14. ALCAIDE N., VARGAS-GARCIA AL., DE LA SERNA-HIGUERA C., SANCHO DEL VAL L., RUIZ-ZORRILLA R., PEREZ-MIRANDA M. EUS-guided drainage of liver abscess by using a lumen-apposing metal stent (with video). Gastrointest Endosc. 2013; 78: 941-2.

15. MEDRADO BF., CARNEIRO FO., VILAÇA TG., GOUVEIA TS., FRAZÃO MS., DE MOURA EG., et al. Endoscopic ultrasound-guided drainage of giant liver abscess associated with transgastric migration of a self-expandable metallic stent. Endoscopy. 2013; 45 Suppl 2: E331-2.

16. KAWAKAMI H., KAWAKUBO K., KUWATANi M., KUBOTA Y., ABE Y., KAWAHATA S., et al. Endoscopic ultrasonography-guided liver abscess drainage using a dedicated, wide, fully covered self-expandable metallic stent with flaredends. Endoscopy. 2014; 46 Suppl 1 UCTN: E982-3.

17. KODAMA R., SAEGUSA H., USHIMARU H., IKENO T., MAKINO M., KAWAGUCHI K. Endoscopic ultrasonographyguided drainage of infected intracystic papillary adenocarcinoma of the liver. Clin J Gastroenterol. 2015; 8: 335-9.

18. KOIZUMI K., MASUDA S., UOJIMA H., ICHITA C., TOKORO S., SASAKI A., et al. Endoscopic ultrasound-guided drainage of an amoebic liver abscess extending into the hepatic subcapsular space. Clin J Gastroenterol. 2015; 8: $232-5$.

19. OGURA T., MASUDA D., SAORI O., WATARU T., SANO T., OKUDA A., et al. Clinical Outcome of Endoscopic UltrasoundGuided Liver Abscess Drainage Using Self-Expandable Covered Metallic Stent (with Video). Dig Dis Sci. 2016; 61: 303-8.

20. TONOZUKA R., ITOI T., TSUCHIYA T., SOFUNI A., ISHII K., IKEUCHI N., et al. EUS-guided drainage of hepatic abscess and infected biloma using short and long metal stents (with videos). Gastrointest Endosc. 2015; 81: 1463-9.

21. KUMTA NA., TORRES-RUIZ F., REINOSO PJ., KAHALEH M. Endoscopic management of hepatic abscess after EUS-guided hepaticogastrostomy. Gastrointest Endosc. 2016; 84: 1054-5.

22. YAMAMOTO K., ITOI T., TSUCHIYA T., TANAKA R., NAGAKAWA Y. EUS-guided drainage of hepatic abscess in the right side of the liver of a patient with Chilaiditi syndrome. VideoGIE. 2017; 2: 299-300.

23. CARBAJO AY., BRUNIE VEGAS FJ., GARCÍA-ALONSO FJ., CIMAVILLA M., TORRES YUSTE R., GIL-SIMÓN P., et al. Retrospective cohort study comparing endoscopic ultrasound-guided and percutaneous drainage of upper abdominal abscesses. Dig Endosc. 2019; 31: 431-8.

24. VENKATESH V., RANA SS., KUMAR A., ANEJA A., LAL SB. Hepatobiliary and Pancreatic: EUS-guided drainage of a ruptured amoebic liver abscess in a child. J Gastroenterol Hepatol. 2020; 35: 921.

25. PETRONE MC., ARCIDIACONO PG. EUS-Guided Drainage of Liver Abscesses: Ultra Uncertain or Sound Practice? Dig Dis Sci. 2016; 61: 8-10.

Received $7^{\text {th }}$ October 2020 